\title{
Analisis Pendapatan Dan Pengaruh Sarana Produksi Usahatani Tanaman Porang (Amorphophalus muelleri) Di Desa Guyangan Kecamatan Winong Kabupaten Pati
}

\section{(Income Analysis And Influence Of Production Facilities Porang Plant (Amorphophalus muelleri) Crops In Guyangan Village, Winong District, Pati District)}

\author{
Dwi Kambali ${ }^{1}$, Saparto dan Eko Suharyono ${ }^{2)}$ \\ ${ }^{1)}$ Mahasiswa Sekolah Tinggi Ilmu Pertanian Semarang \\ ${ }^{2)}$ Dosen Sekolah Tinggi Ilmu Pertanian Semarang \\ JIn. Pawiyatan Luhur IV/16 Semarang \\ ekosuharyono.farming@gmail.com
}

\begin{abstract}
ABSTRAK
Penelitian ini bertujuan untuk mengkaji pendapatan bersih dan pengaruh sarana produksi (biaya benih, pupuk Urea, pupuk NPK Ponska, pupuk kandang, pestisida) dan tenaga kerja terhadap pendapatan bersih usahatani tanaman porang di bawah tegakan tanaman di desa Guyangan kecamatan Winong kabupaten Pati. Metode penelitian yang digunakan dalam penelitian ini adalah metode deskriptif analisis. Analisis data menggunakan analisis pendapatan bersih dan regresi linier berganda. Hasil penelitian usahatani tanaman porang di desa Guyangan kecamatan Winong kabupaten Pati memberikan pendapatan bersih sebesar Rp 20.306.341,7/ha/musim tanam, dan sarana produksi berupa biaya benih, pupuk NPK Ponska, pupuk kandang dan biaya pestisida berpengaruh terhadap pendapatan bersih usahatani tanaman porang.
\end{abstract}

Kata kunci : Pendapatan bersih, sarana produksi, tanaman porang

\section{ABSTRACT}

This study aims to examine the net income and the influence of production facilities (seed costs, urea fertilizer, NPK Ponska fertilizer, manure, pesticides) and labor on net income of porang farming under plant stands in the village of Guyangan, Winong district, Pati district. The research method used in this research is descriptive analysis method. Data analysis uses net income analysis and multiple linear regression. The results of research on porang crop farming in Guyangan village, Winong sub-district, Pati regency provide net income of Rp 20,306,341.7 / ha / planting season, and production facilities in the form of seed costs, NPK Ponska fertilizer, manure and pesticide costs affect the net income of crop farming porang.

Keywords: Net income, production facilities, porang plants.

\section{Latar Belakang}

\section{PENDAHULUAN}

Tanaman umbi-umbian di Indonesia mempunyai keragaman jenis dan manfaat dari umbinya yang relatif banyak. Keragaman jenis tanaman umbiumbian seperti : uwi, suweg, ketela pohon, ketela rambat, gayong, porang dan lainlainnya. Keragaman manfaat dari umbi tanaman tersebut meliputi sebagai sumber karbohidrat, bahan perekat, bahan pembalut dan lain-lainnya
(Ramdana dan Suhartati, 2015).

Tanaman porang (Amorphophalus muelleri) merupakan salah satu tanaman umbi-umbian di Indonesia yang memiliki manfaat dari umbi yang lebih beragam dari pada tanaman umbi-umbian yang lainnya. Tanaman porang mengandung karbohidrat yang penting yaitu glucomanan. Kandungan glucomanan pada tanaman porang paling tinggi dibandingkan dengan tanaman umbiumbian lainnya, dan juga merupakan satu- 
satunya sumber glukomanan bukan pohon yang cukup tinggi. Adanya glukomanan membuat tanaman porang tidak hanya sebagai bahan pangan tetapi dapat digunakan sebagai bahan lem ramah lingkungan dan pembuatan komponen pesawat terbang (Ramadhani, 2019).

Saat ini tren permintaan porang dipasar dunia terus meningkat, sehingga banyak pihak yang tetarik untuk membudidayakan. Di Indonesia tanaman porang belum banyak yang membudidayakan, tanaman tersebut tumbuh di pekarangan atau pinggiran hutan yang tumbuh liar dan berkembangbiak dari umbiunya.

Desa Guyangan merupakan salah satu desa yang terletak di kecamatan Winong kabupaten Pati, dimana sebagian besar penduduk desa Guyangan memiliki pekerjaan sebagai petani, baik sebagai petani pengolah lahan sawah, pengolah lahan kering dan pengolah lahan bawah tegakan tanaman kehutanan. Tanaman porang sudah dikembangkan di Kesatuan Pemangkuan Hutan Pati Perum Perhutani Unit I Jawa Tengah. Tanaman porang juga sudah dikembangkan di kawasan hutan rakyat di desa Guyangan kecamatan Winong. Petani di desa Guyangan dalam melakukan usahatani tanaman porang masih dilakukan secara konvensional dengan kurang memperhatikan faktorfaktor produksi.

Penelitian bertujuan untuk mengkaji pendapatan dan pengaruh sarana produksi (biaya benih, pupuk Urea, pupuk NPK Ponska, pupuk kandang, pestisida) dan tenaga kerja terhadap pendapatan usahatani tanaman porang di bawah tegakan tanaman di desa Guyangan kecamatan Winong kabupaten Pati.

\section{METODE PENELITIAN}

Penelitian dilakukan di Desa Guyangan Kecamatan Winong Kabupaten Pati pada bulan Januari 2018 sampai Mei 2018. Penentuan lokasi ditentukan dengan secara Purposive Sampling, dengan pertimbangan daerah tersebut merupakan daerah yang memiliki petani tanaman porang paling banyak di kecamatan Winong kabupaten Pati.

Metode yang digunakan dalam penelitian ini adalah metode deskriptif analisis. Metode ini bertujuan mendapatkan gambaran tentang usahatani, misal biaya benih/bibit, pupuk, biaya tenaga kerja, penerimaan dan pendapatan.

Subyek penelitian adalah petani tanaman porang pada kelompok tani "Tani Lestari" di desa Guyangan kecamatan Winong kabupaten Pati. Berdasarkan hasil prasurvei, diperoleh populasi (jumlah petani) yang budidaya tanaman porang di bawah tegakan sebanyak 170 dengan luas kepemilikin yang beragam antara $0,100 \mathrm{~s} / \mathrm{d} 0,670$ ha. Jumlah sampel diambil dengan menggunakan teknik sampling acak bertingkat (stratified random sampling) berdasarkan luas tanah masing - masing petani. Karena jumlah populasi 170 orang maka sesuai Arikunto (2006) jumlah sampel dapat diambil $20 \%$ yaitu $170 \times 20$ $\%=34$ orang.

Analisis pendapatan usahatani tanaman porang dapat dilihat dari total biaya atau pengeluaran yaitu semua nilai faktor produksi yang digunakan untuk menghasilkan suatu produk. Pendapatan kotor merupakan nilai produk usahatani yang dikalikan dengan total produksi periode tertentu, sedangkan pendapatan bersih merupakan selisih antara total biaya dan pendapatan kotor (Soekartawi, 2006) 


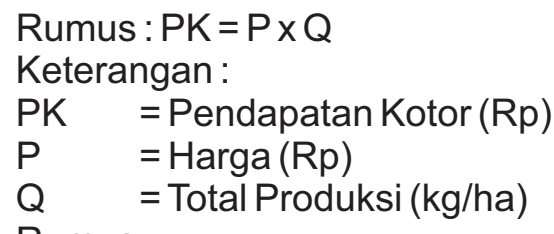

Rumus:

Pendapatan Bersih $(\mathrm{PB})=$ Pendapatan Kotor $(\mathrm{PK})-$ Total Biaya $(\mathrm{TB})$.

Analisis Regresi Linear Berganda adalah untuk mengetahui seberapa besar pengaruh faktor biaya produksi dan tenaga kerja terhadap pendapatan usahatani tanaman porang, dimana sarana produksi (benih, pupuk Urea, pupuk NPK Ponska, pupuk kandang, pestisida, tenaga kerja ) sebagai variabel bebas $\left(X_{1}, X_{2}, X_{3}, X_{4}, X_{5}, X_{6}\right)$ dan pendapatan bersih sebagai variabel terikatnya $(Y)$, sehingga persamaan Regresi Linear Berganda menggunakan rumus sebagai berikut:

$$
Y=a+b_{1}+b_{1} X_{1}+b_{2} X_{2}+b_{3} X_{3} b_{4} X_{4}+b_{5} X_{5}+b_{6} X_{6+\varepsilon}
$$

Keterangan :

Y = Pendapatan Bersih(Rp)

a = Konstanta regresi

$\mathrm{b}_{1} \ldots \mathrm{b}_{6}=$ Koefisien regresi

$\mathrm{X}_{1} \quad=$ Biaya benih (Rp)

$\mathrm{X}_{2} \quad=$ Biaya pupuk Urea $(\mathrm{Rp})$

$\mathrm{X}_{3} \quad=$ Biaya pupuk NPK $(\mathrm{Rp})$

$\mathrm{X}_{4} \quad=$ Biaya pupuk Kandang (Rp)

$\mathrm{X}_{5} \quad=$ Biaya pestisida $(\mathrm{Rp})$

$\mathrm{X}_{6} \quad=$ Biaya tenaga kerja $(\mathrm{Rp})$

Hipotesis yang digunakan adalah sebagai berikut :

Hipotesis statistik:

$\mathrm{H}_{\mathrm{o}}: \mathrm{b}=\mathrm{O} \rightarrow$ artinya variabel independen (sarana produksi benih, pupuk (Urea, NPK Ponska, pupuk kandang), pestisida dan faktor tenaga kerja) bukan secara partial atau individu merupakan penjelas yang berpengaruh terhadap variabel dependen (pendapatan bersih) dengan kata lain berarti tidak ada pengaruh .
$\mathrm{H}_{\mathrm{a}}: \mathrm{b} \neq \mathrm{O} \rightarrow$ artinya variabel independen (sarana produksi benih, pupuk (Urea, NPK Ponska, pupuk kandang), pestisida dan faktor tenaga kerja ) secara partial, berpengaruh secara signifikan terhadap variabel dependen (pendapatan bersih).

Dengan menggunakan tingkat kepercayaan $95 \%$ atau $\alpha 5 \%$.

\section{HASIL DAN PEMBAHASAN \\ Pendapatan Bersih Usahatani Tanaman Porang}

Data analisis pendapatan bersih usahatani tanaman porang didapatkan dari hasil quisioner responden yaitu anggota kelompok tani Tani Lestari Desa Guyangan kecamatan Winong kabupaten Pati sebanyak 34 petani. 
Tabel 1. Rata-rata Biaya Produksi, Pendapatan Kotor dan Pendapatan Bersih Tanaman Porang per Hektar per Musim Tanam

\begin{tabular}{llr}
\hline No & \multicolumn{1}{c}{ Uraian } & Jumlah (Rp) \\
\hline 1 & Biaya Tetap & \\
& a. Biaya Sewa Lahan & $5,388.544,1$ \\
& b. Biaya Pajak & $165.575,3$ \\
& C. Penyustan Alat & $219.602,9$ \\
& Total Biaya Tetap & $5.773 .722,3$ \\
2 & Biaya Variabel & \\
& a. Biaya Benih & $6.347 .129,9$ \\
& b. Biaya Pupuk Kandang & $4.642 .644,9$ \\
& C. Biaya Pupuk Urea & $527.796,0$ \\
& d. Biaya Pupuk NPK & $562.005,0$ \\
& C. Biaya Pestisida & $1.069 .941,9$ \\
& d. Biaya Tenaga Kerja & $7.388 .457,0$ \\
3 & Total Biaya Variabel & $20.537 .972,7$ \\
4 & Total Biaya Produksi & $26.311 .695,6$ \\
5 & Produksi (kg) & $18.647,2$ \\
6 & Harga (Rp/kg) & $2.500,0$ \\
7 & Pendapata Kotor & $46.618 .036,8$ \\
\hline
\end{tabular}

Sumber : Analisis Data Primer (2018)

\section{Biaya Tetap}

Biaya tetap adalah biaya yang besarnya tetap dan tidak tergantung jumlah barang yang diproduksi serta harus dibayarkan berapapun jumlah produksi yang dihasilkan. Berdasarkan Tabel 1 rata - rata biaya tetap $\mathrm{Rp}$ 5.773.722,3/ha/musim tanam. Biaya tetap ini meliputi biaya sewa lahan ,pajak dam penyusutan alat. Lahan yang digunakan untuk usahatani tanaman porang ini adalah lahan di bawah tanaman/tegakan jati dengan jenis tanah latosol. Tanah latosol ini tergolong tanah yang kaya akan hara karena mempunyai cadangan sumber hara yang tinggi denga $\mathrm{pH}$ netral sampai alkali.

2. Biaya Variabel

Biaya variabel adalah biaya yang harus dibayar sebanding dengan jumlah produksi yang dihasilkan. Menurut Tabel 1. rata-rata biaya variabel yaitu $R p$ 20.537.972,7/ha/musim tanam. Biaya variabel ini meliputi : biaya benih, biaya pupuk (Urea, NPK dan kandang).
Biaya benih dalam usahatani tanaman porang sebesar Rp $6.347 .127,9 / \mathrm{ha} / \mathrm{musim}$. Benih porang dalam usahatani tanaman porang di desa Guyangan kecamatan Winong ini berasal dari umbi (bagian vegetaif) tanaman porang yang sudah berumur 1 tahun, sedangkan menurut Anonim (2013) benih tanaman porang diambil dari umbi batang yang tumbuh sehat dan subur serta tanaman berumur 1 tahun. Umbi porang tersebut sebelum ditanam/disemai harus diseleksi dahulu agar mendapatkan pesen jadi tanaman/bibit yang tinggi, dengan persen jadi tanaman yang tinggi diharapkan akan diperoleh hasil umbi porang yang tinggi pula. Rata-rata penggunaan benih umbi porang di desa Guyangan kecamatan Winong sebesar $1.269,4 \mathrm{~kg} / \mathrm{ha}$, sedangkan menurut Anonim (2013) kebutuhan benih sebanyak $1.500 \mathrm{~kg} / \mathrm{ha}$ (20 - $30 \mathrm{umbi} / \mathrm{kg}$ )

Biaya pupuk dalam usahatani tanaman porang di desa Guyangan kecamatan Winong sebesar Rp 
5.732.445,9/ha/musim. Pupuk yang digunakan dalam usahatani porang di desa Guyangan kecamatan Winong adalah pupuk kandang, Urea dan NPK Ponska. Pupuk kandang diberikan untuk pemupukan dasar pada awal tanam, pupuk kandang ini hanya memiliki kandungan hara yang sedikit, fungsi utamanya adalah untuk memperbaiki sifat fisika tanah. Pupuk Urea digunakan untuk memacu pertumbuhan vegetatif tanaman porang yang diberikan pada awal musim penghujan. Sedangkan pupuk NPK Ponska digunakan untuk pertumbuhan generatif (biji) dan vegetaif (umbi). Menurut Sudirman (2020) untuk menghasilkan tanaman porang dengan hasil umbi yang baik maka dibutuhkan pupuk Urea sebanyak $300 \mathrm{~kg} / \mathrm{ha}$ dan pupuk Ponska $300 \mathrm{~kg} / \mathrm{ha}$. Kebutuhan pupuk Urea dan Ponska dalam usahatani tanaman porang di desa Guyangan kecamatan Winong adalah : pupuk Urea sebanyak 293,2 kg/ha dan NPK phonska sebanyak $244,4 \mathrm{~kg} / \mathrm{ha}$.

Biaya pestisida dalam usahatani tanaaman porang di desa Guyangan kecamatan Winong kabupaten Pati sebesar Rp 1.069.941,9/ha/tanam. Dalam budidaya tanaman porang sering kali juga terkena hama dan penyakit. Kebanyakan hama yang sering menyerang tanaman porang adalah ulat makasar orketti dan nematoda. Sedangkan penyakit umum porang adalah busuk batang semu, layu daun oleh jamur. Pengendalian nematoda jenis Heterodera yang sering menyerang umbi porang dapat menggunakan Carbofuran/Furadan, sedangkan pengendalian penyakit dapat gunakan fungisida Ridomil dan Benlate.

Biaya tenaga kerja dalam usahatani tanaaman porang di desa Guyangan kecamatan Winong kabupaten Pati sebesar Rp 7.388.457,0/ha/tanam.
Biaya tenaga kerja meliputi penyiapan lahan, penanaman, pemeliharaan ( $p$ enyiangan, pemupukan, pemberantasan hama dan penyakit) dan panen.

3. Pendapatan kotor

Pendapatan kotor usahatani tanaman porang di desa Guyangan kecamatan Winong berasal dari total hasil penjualan umbi. Rata- rata produksi usahatani tanaman porang di kelompok tani Tani Lestari sebesar 18.647,2 kg/ha, sedangkan harga umbi porang sebesar $\mathrm{Rp} 2.500 / \mathrm{kg}$, sehingga didapatkan pendapatan kotor sebesar Rp 46.618.341,7/ha. Menurut Anonim (2013) untuk luasan lahan 1 hektar dapat ditanam 6.000 bibit, sehingga dapat menghasilkan 24 ton/ha dengan harga umbi porang $\mathrm{Rp}$ $2.500 / \mathrm{kg}$ akan didapatkan penerimaan sebesar Rp 60.000.000/ha. Di desa Guyangan kecamatan Winong peningkatan produksi umbi porang dapat ditingkatkan dengan perbaikan dalam budidaya terutama dalam penggunaan pupuk NPK Ponska perlu ditambah sehingga akan merangsang pertumbuhan tanaman porang baik pertumbuhan vegetatif dan generatif.

4. Pendapatan bersih

Pendapatan bersih merupakan hasil dari pengurangan antara penerimaan dan total biaya produksi. Berdasarkan Tabel 1. didapatkan rata-rata pendapatan bersih sebesar $\mathrm{Rp}$ 20.306.341,7/ha/musim tanam.

\section{Analisis Regresi Linier Berganda Usahatani Tanaman Porang}

Analisis regresi linier berganda digunakan untuk mengetahui pengaruh variabel bebas $(X)$ terhadap variabel terikat $(\mathrm{Y})$. Variabel bebas yang digunakan meliputi biaya benih $\left(X_{1}\right)$, biaya pupuk Urea $\left(X_{2}\right)$, biaya pupuk NPK $\left(X_{3}\right)$, biaya 
pupuk kandang $\left(\mathrm{X}_{4}\right)$, biaya pestisida $\left(X_{5}\right)$, biaya tenaga kerja $\left(X_{6}\right)$ terhadap pendapatan bersih $(\mathrm{Y})$ sebagai variabel terikat. Analisis regresi diolah menggunakan aplikasi SPSS 19.0 for Windows dan diperoleh hasil sebagai berikut.

Persamaan regresi linier berganda :

$Y=30654,94+2,13 X_{1}^{* *}-4,37 X_{2}{ }^{n s}+22,79 X_{3}^{* *}+1,82 X_{4}^{* *}-5,02 X_{5}^{* *}+0,05 X_{6}^{n s}$

1. Hasil analisis regresi linier berganda menunjukan bahwa nilai a (konstanta) sebesar 30.654,94 yang artinya apabila kegiatan usahatani tanaman porang tidak dilakukan atau tidak ada penggunaan biaya benih $\left(X_{1}\right)$, biaya pupuk Urea $\left(X_{2}\right)$, , biaya pupuk NPK $\left(X_{3}\right)$, , biaya pupuk kandang $\left(X_{4}\right)$, biaya pestisida $\left(X_{5}\right)$ dan biaya tenaga kerja $\left(\mathrm{X}_{6}\right)$ rata rata pendapatan bersih usahatani tanaman porang di kelompok tani Tani Lestari desa Guyangan kecamatan Winong kabupaten Pati Rp 30.654,94.

2. Nilai koefisien regresi biaya benih $\left(\mathrm{X}_{1}\right)$ sebesar 2,13 artinya apabila biaya benih ditingkatkan $\mathrm{Rp}$ 1,- maka pendapatan bersih ( $Y$ ) akan naik sebesar Rp 2,13. Biaya benih $\left(X_{1}\right)$ berpengaruh sangat signifikan terhadap pendapatan bersih usahatani tanaman porang. Biaya benih sangat ditentukan oleh jumlah benih yang digunakan untuk usahatani tanaman porang. Bahan tanaman yang digunakan dalam usahatani tanaman porang di desa Guyangan menggunakan bibit. Kebutuhan benih tanaman porang di desa Guyangan sebanyak 40.00 bibit per hektar. Sedangkan menurut Mutmaidah dan Rozi (2015) dengan jarak tanam adalah $50 \times 50 \mathrm{~cm}^{2}$. Kebutuhan benih per hektar untuk umbi $1.500 \mathrm{~kg}$ ( $\pm 20-30 \mathrm{buah} / \mathrm{kg}$ setara $37.500 \mathrm{bibit} / \mathrm{ha}$ ), sehingga dalam usahatani tanaman porang di desa Guyangan kecamatan Winong masih dapat ditambah dengan pengurangan jarak tanam. Porang ditanam ketika awal musim hujan, sekitar bulan September sampai akhir Oktober. Tiap lubang tanaman diisi 1 benih dengan letak bakal tunas menghadap ke atas kemudian ditutup dengan tanah halus / tanah olahan $\pm 3 \mathrm{~cm}$. Hasil penelitian Mutmaidah dan Rozi (2015), mengenai Peluang Peningkatan Pendapatan Masyarakat Tepi Hutan Melalui Usahatani Porang, Iahan yang digunakan adalah lahan di bawah tegakan hutan terutama tanaman jati dengan umur tanaman di atas 3 tahun. Lahan dibersihkan dari gulma dan tidak perlu diolah (minimum telage), buat lubang tempat ruang tumbuh bibit.

3. Nilai koefisien regresi biaya pupuk Urea $\left(\mathrm{X}_{2}\right)$ menunjukan angka 4,37 yang dapat diartikan bahwa biaya penggunaan pupuk Urea perlu dikurangi. Biaya penggunaan pupuk Urea tidak berpengaruh secara signifikan terhadap pendapatan bersih usahatani tanaman porang di desa Guyangan. Pupuk Urea merupakan sumber unsur Nitrogen, pupuk Urea ini berfungsi untuk 
memacu pertumbuhan daun dan batang, memberikan warna gelap pada daun dan memperbaiki kualitas daun dan diperlukan utnuk pembentukan protein sel dan khlorofil. Dalam usahatani tanaman porang hasil akhir yang diharapkan adalah berupa umbi, sehingga pupuk yang fungsinya untuk pertumbuhan daun kurang dibutuhkan.

4. Nilai koefisien regresi biaya pupuk NPK $\left(X_{3}\right)$ menunjukan angka 22,79 yang dapat diartikan bahwa biaya penggunaan pupuk NPK masih dapat ditambah. Biaya penggunaan pupuk NPK sangat berpengaruh signifikan terhadap pendapatan bersih usahatani tanaman porang di desa Guyangan. Pupuk NPK merupakan pupuk majemuk dan merupakan sumber unsur Nitrogen, Phosphor dan Kalium. Dalam usahatani tanaman porang penggunaan pupuk majemuk sangat dibutuhkan, tujuan penggunaan pupuk majemuk tersebut adalah untuk menjaga terpeliharanya keseimbangan unsur hara dalam tanah, serta meningkatkan pertumbuhan dan produksi tanaman. Pupuk majemuk tersebut dapat berupa pupuk Phonska dengan kandungan $\mathrm{N} 15 \%, \mathrm{P}_{2} \mathrm{O}_{5}$ $15 \%, \mathrm{~K}_{2} \mathrm{O} 15 \%$ dan S $10 \%$. Pemberian pupuk NPK ini dapat dilakukan sekali dalam satu tahun, yang diberikan pada awal musim penghujan.

5. Nilai koefisien regresi biaya pupuk kandang $\left(\mathrm{X}_{4}\right)$ menunjukan angka 1,82 yang dapat diartikan bahwa biaya penggunaan pupuk kandang dapat ditambah. Biaya penggunaan pupuk kandang sangat berpengaruh signifikan terhadap pendapatan bersih usahatani tanaman porang di desa Guyangan. Pupuk kandang merupakan pupuk yang berasal dari kotoran huwan yang digunakan untuk menyediakan unsur hara bagi tanaman. Pupuk kandang berperan untuk memperbaiki sifat fisik, kimia dan biologi tanah, namun karena kandungan hara yang sedikit bila dibanding pupuk organik, peran memperbaiki sifat fisik dan biologis lebih menonjol. Di desa Guyangan dalam usahatani tanaman porang, pemberian pupuk kandang diberikan pada awal tanam, sehingga berfungsi sebagai pupuk dasar. Pupuk kandang yang diberikan pada awal tanam kebanyakan berasal dari kotoran sapi yang dipelihara oleh petani. Pupuk kandang ini dalam usahatani tanaman porang lebih berfungsi untuk mempurbaiki sifat fisik dan biologi tanah, sehingga tanah lebih gembur sehingga akan sangat membantu dalam proses pembentukan umbi tanaman porang.

6. Nilai koefisien regresi variabel biaya pestisida $\left(X_{5}\right)$ adalah - 5,02 artinya penggunaan pestisida perlu dikurangi. Biaya penggunaan pestisida sangat berpengaruh signifikan terhadap pendapatan bersih usahatani tanaman porang di desa Guyangan. Dalam usahatani tanaman porang di desa Guyangan kecamatan Winong hama yang sering menyeran tanaman porang adalah ulat (Makasar orketti). Untuk pengendalian hama dan penyakit pada tanaman porang dapat 
dilakukan sejak awal tanam dan dilakukan pengendalian hama dan penyakit secara terpadu. Pemberantasan hama dan penyakit dengan menggunakan bahan kimia sebaiknya ditiadakan, Dalam usahatani tanaman porang di desa Guyangan ini sebaiknya penggunakan pestisida dikurang, sehingga akan dapat mengurangi biaya pembelian pestisida. Dalam pengendalian hama dan penyakit secara perpadu diusahakan pertumbuhan tanaman porang harus selalu sehat, hal ini dapat dilakukan dengan pemilihan bibit yang sehat yang terbebas dari hama dan penyakit.

7. Nilai koefisien regresi biaya tenaga kerja $\left(\mathrm{X}_{6}\right)$ adalah 0,05 artinya penggunaan tenaga kerja perlu ditambah. Biaya penggunaan tenaga kerja tidak berpengaruh signifikan terhadap pendapatan bersih usahatani tanaman porang di desa Guyangan. Sebagain besar masyarakat di desa Guyangan kecamatan Winong kabupaten Pati adalah bermata pencaharian sebagai petani. Komuditas utama yang diusahakan adalah tanaman padi, sehingga penanaman porang dibawah tegakan hutan sebagian besar hanyalah sebagai usaha sambilan. Dalam usahatani tanaman porang pengolahan tanah dilakukan dengan semi intensif sehingga tidak perlu semua tanah diolah. Penanaman dan pemeliharaan tanam juga tidak memerukan tenaga kerja yang banyak, sebagai contoh pemupukan susulan (NPK) hanya dilakukan sekali dalam satu tahun.

\section{KESIMPULAN}

1. Usahatani tanaman porang di desa Guyangan kecamatan Winong kabupaten Pati memberikan pendapatan bersih sebesar Rp 20.306.341,7/ha/musim tanam.

2. Sarana produksi berupa biaya benih, pupuk NPK Ponska, pupuk kandang dan biaya pestisida berpengaruh terhadap pendapatan bersih usahatani tanaman porang.

\section{DAFTAR PUSTAKA}

Anonim, 2013. Budidaya Dan Pengembangan Porang (Amorphophallus muelleri Blume) Sebagai salah Satu Potensi Bahan Baku Lokal, Universitas Brawijaya. Malang.

Arikunto,2006. Prosedur Penelitian Suatu Pendekatan Praktek.Rineka Cipta. Jakarta.

Hermanto. F. 1996. IImu Usahatani. $P$ e $n$ e b a $r \quad S$ w a d a y a. Jakarta.Pekajaman, 2019. https://www.infoporangindonesia.com/ 2019/08/panduan-lengkap-carabudidaya-porang

Ramdana.S. dan Suhartati,2015. Tumbuhan Porang, Prospek Budidaya Sebagai Salah Satu Sistem Agroforestry. Balai Penelitian Kuhutanan Makasar. Makasar

Ramadhani.Y, 2019. Mengenal Tanaman Porang, Manfaat, harga, Budidaya Dan Nilai Bisnis. Tirto.id.

Soekartawi. 2006. Ilmu Usahatani dan Penelitian Untuk Pengembangan Petani Kecil. Jakarta; Universitas Indonesia.

Sudirman, 2020. Teknik Budidaya Porang. BPP Sinjai Selatan 